\title{
Comparison of several methods of stands inventory prior to logging towards the yield volume of mangrove forest in Bintuni Bay, West Papua Province, Indonesia
}

\author{
ISTOMO`, CECEP KUSMANA, FIFI GUS DWIYANTI, DZULFIKAR MALIK \\ Department of Silviculture, Faculty of Forestry, Institut Pertanian Bogor. Jl. Ulin, Kampus IPB Dramaga, Bogor 16680, West Java, Indonesia. \\ Tel.: +62-251-8626806, Fax.: +62-251-8626886, `email: Istomo19@gmail.com
}

Manuscript received: 10 January 2020. Revision accepted: 14 March 2020.

\begin{abstract}
Istomo, Kusmana C, Dwiyanti FG, Malik D. 2020. Comparison of several methods of stands inventory prior to logging towards the yield volume of mangrove forest in Bintuni Bay, West Papua Province, Indonesia. Biodiversitas 21: 1438-1447. The difference between the estimated volume and the actual harvested volume is the reason that mangrove forest management is unsustainable. To overcome this discrepancy, it is important to do what so called Inventarisasi Tegakan Sebelum Penebangan (ITSP) or stands inventory prior to logging for logging concession. However, the study on suitable ITSP methods for mangrove forests has been limited. This study aims to assess three ITSP methods (namely Line Strip Sampling Method, Line Systematic Sampling Method, and CIFOR's Modified Method) using two allometric equations (i.e., equation developed specifically by a logging concession and equation developed that has specific formula for each species), and to select the combination of method and allometric equation that produce the highest accuracy for logging concession in mangrove forest, especially in Bintuni Bay, West Papua. The results showed that CIFOR's Modified Method produces the lowest discrepancy between the estimated volume and the actual harvested volume, followed by Line Strip Sampling Method. In addition, regardless of the ITSP methods employed, the allometric equation by Cole et al. (1999) outperforms the equation developed specifically by a logging concession. While producing the lowest discrepancy with plot size is the smallest than other methods, CIFOR's Modified Method has a disadvantage when applied in the field due to difficulties in making a circular plot. As such, we recommend ITSP method to be used is the Line Strip Sampling method with allometric equation.
\end{abstract}

Keywords: CIFOR's modified, ITSP, Line Strip Sampling, Line Systematic Sampling, volume

\section{INTRODUCTION}

Mangrove forests are tropical and subtropical vegetation communities located in coastal areas. They are dominated by several species of mangrove trees that are able to grow and survive and can develop in tidal areas. Mangrove forest have habitat characteristics including it is generally in intertidal areas where soil types are muddy, argillaceous and/or sandy, the area is periodically flooded with seawater in a daily basis, inundation frequencies determine the composition of mangroves and it can receive sufficient freshwater supply from land and it protects from waves and tidal strong currents (Nontji 2002). The direct benefits of mangroves include fisheries, wood, food, animal feed, medicinal materials and raw materials for industrial use (Van Oudenhoven et al. 2015), raw materials used for wood pellet production (de Ramos et al. 2017) as well as tourism and education (Setyawan and Winarno 2006; Mitra et al. 2011; Alongi 2012).

As of 2011, an estimated area of the world's mangrove forests reached 13 million hectares with $42 \%$ of these are located in Asia (Giri et al. 2011). In 2009, the extent of mangrove forests in Indonesia was estimated at 3.2 million ha (Saputro et al. 2009), while another source (Giri et al. 2011) stated Indonesia has 3.1 million ha of mangroves which ranks Indonesia as the country with the largest mangrove area in the world $(22.6 \%$ of the world's total mangroves). Yet, this number continues to decrease at a significant rate with estimation of up to 800,000 ha in the last three decades (de Ramos et al. 2017). The decline in area of mangrove forests not only happens in Indonesia but also around the world with estimation of $35 \%$ decrease over the last two decades (Valiela et al. 2001) with deforestation rates of up to 1-3\% per year (Alongi 2012). Therefore, good management is needed to ensure the sustainability of mangroves' natural resources (Kusmana et al. 2018).

Sustainable management of mangrove forests in Indonesia is a concern for government and private parties to conserve the remaining mangrove ecosystems through various means including reforestation, sustainable harvesting and silvicultural practices, and also attention to the ability of natural regeneration (de Ramos et al. 2017; Istomo et al. 2017). The management of mangrove forests in Java has already been directed to maximize the ecotourism potential of the forest (Van Oudenhoven et al. 2015), while the management of mangrove forests outside the island of Java is still exploiting the potential forest products in the form of wood (de Ramos et al. 2017). This is particularly eminent in a region where mangrove forests still to a large extent, such as in Bintuni Bay, West Papua, Indonesia. Satellite imagery released by Forest Watch Indonesia (FWI) (2001) showed that $11 \%$ of Indonesia's mangroves are located in Bintuni Bay and is considered to 
be the largest mangrove forest in Southeast Asia. Currently, some part of mangrove forest in this area is managed for logging concession in the form of IUPHHK-HA (Izin Usaha Pemanfaatan Hasil Hutan Kayu pada Hutan Alam or Business Permit for the Utilization of Wood ForestNatural Forest Products).

In general, the permit of IUPHHK-HA is granted instate forest (Kawasan Hutan) allocated for production function (Hutan Produksi). The permit allows the managing parties, usually logging concession, to manage the forest in a particular period which can be renewed once the permit expired. The management regime of IUPHHKHA usually implements selective logging in a natural forest with a particular period of cutting rotation (e.g., 25 years) in which once the forest is logged, it would be left to recover until the next cutting rotation. Often, enrichment planting is required to accelerate the recovery and to increase forest productivity. By regulation, the managing party is required to do stands inventory prior to logging or termed as Inventarisasi Tegakan Sebelum Penebangan (ITSP) to assess the potential of harvestable wood.

Stands inventory prior to logging or ITSP is an initial step to find out the potential of wood of a forest (Wanggai 2009) that is conducted two or three years before timber harvesting. In the context of rotational logging, this activity is useful to know the composition of the tree species and the structure of the stand, especially after the timber harvesting in the previous cycle followed by natural regeneration. Pribadi (1998) states that changes in the environment will change in the structure of stands and species composition of forest including mangroves. In addition to changes in the environmental landscape, stand structure and composition may also change due to human activities, ranging from management interventions (such as enrichment planting, climber liberation) to illegal logging activities, and natural disturbances (e.g. fires and winds) (FAO 2001; Mirmanto 2010). The information on the structure and species composition are also useful in predicting the growth rate of a forest stand to establish a sustainable management or forest system (Cole et al. 1999; Gasparini et al. 2017). In principle, ITSP aims to maintain the sustainability of stands by estimating the species, number, and volume of trees to be harvested, as well as identifying the species and composition of trees that will be left in the field to be maintained until the next harvest cycle. Therefore, it is necessary to evaluate the activities carried out before and after forest harvesting.

The ITSP process is an important stage for future decisions of sustainable forest management. The difference between the volume resulted from the ITSP activity and the volume of the actual harvest can cause financial losses or overexploitation on the contrary. Therefore, the ITSP can determine sustainability in term of financial and long-term production of forest management. A proper ITSP method should generate an estimation closest to the actual harvested volume. Based on these problems, this study aims to assess three ITSP methods (namely Line Strip Sampling Method, Line Systematic Sampling Method, and CIFOR's Modified Method) using two allometric equations (i.e. equation developed specifically by a logging concession and equation developed by Cole et al. (1999)), and to select the combination of method and allometric equation that produce the highest accuracy for IUPHHKHA in mangrove forest, especially in Bintuni Bay, West Papua, Indonesia.

\section{MATERIALS AND METHODS}

\section{Study period, area and context}

This research was conducted from 28 March to 7 April 2016 on an IUPHHK-HA in mangrove forest managed by a logging concession company. The study area is located in the sub-district of Babo, Teluk Bintuni District, West Papua Province (Figure 1). The logging concession has managed the mangrove forests for 27 years that will expire in 2053, and it has a certificate of Sustainable Management of Production Forests (SMPF) or Pengelolaan Hutan Produksi Lestari (PHPL) in 2011 (Friess et al. 2016). In the first 25 years of cutting rotation, the logged-over forest following previous cut showed good recovery (Silanpaa et al., 2017). In accordance with the Decree of the Director General of Forestry No: 60/Kpts/DJ/I/1978, the management of mangrove forests in Bintuni Bay implements a silvicultural system of seed trees which is maintained at $\geq 40$ trees/ha (Ministry of Agriculture 1978). However, the regulation on the density of seed trees has been revised to $\geq 25$ trees/ha through the regulation of the Director General of Sustainable Production Forest Management (P.8/PHPL/SET/3/2016) (Ministry of Environment and Forestry 2016).

The total area of the logging concession is 82,120 ha with the utilization of mangrove wood is carried out in about $63.5 \%$ of the concession area. Based on the interpretation of satellite Landsat imagery by the Director of Inventory and Monitoring of Forest Resources, the Ministry of Forestry on June 8th, 2009, the land cover in the areas of the logging concession was dominated by primary mangrove forest $(51,486$ ha). The floristic composition in the area was dominated (60\%) by Rhizophora apiculata and $R$. mucronata (Wahyudi et al. 2013). The topography is flat with a slope of less than $2 \%$. This condition is advantageous in carrying out wood harvesting activities. Based on the USDA Soil Taxonomy System, soil types in the study areas are Sulfaquent, Tropopsamen, and Tropudult. Soil parent material is a transported sandy clay sediment.

According to Koppen climate classification, the Babo District and its surroundings are classified into Afa category (high-temperature wet tropics), while according to Schmidt-Ferguson it belongs to type A (very wet areas). Annual rainfall based on statistical data from 1993 to 2003 reached 2,000-4, $400 \mathrm{~mm}$. Rainy days in a year can reach 240 days with the highest in December (22 days) and the lowest in February and September (18 days). The temperature in the Babo district has a maximum value of 30.7 degrees Celsius, a minimum of 21.9 degrees Celsius and an average of 26 degrees Celsius. The maximum and minimum absolute temperatures are 35.5 degrees and 22.6 degrees Celsius. The relative humidity is humid with 
maximum, minimum, and average values of $90 \%, 82 \%$, and $85 \%$, respectively. In December to April, the wind blows from the north and northwest while in May to November, the wind blows from the Southeast. Wind speed in the Babo district is moderate with an average of 3.4 $\mathrm{m} / \mathrm{sec}$.

\section{Procedures}

The working procedure used in this study were divided into two parts, namely data collection and data analysis. The treatments in this study were three ITSP methods used to inventory stands on three logging plots (plot 260, 263, and 266). All three methods were used on the same transect line on each logging plot. The data collected in this study were primary data in the form of vegetational structure of the trees and the regeneration level of the mangrove forest. The definition of tree in this study is an individual woody plant with diameter at breast height of $10 \mathrm{~cm}$ or more, while regeneration level is: (i) sapling, i.e., plant less than $10 \mathrm{~cm}$ in diameter; and (ii) seedlings, i.e., plant with a maximum height of $1.5 \mathrm{~m}$. Data taken at the tree level were (i) Diameter Breast High $(\mathrm{DBH})$ at $1.3 \mathrm{~m}(>10 \mathrm{~cm})$ which was measured using a diameter tape, and (ii) the species name on the ITSP pathway. Whereas, the data taken at seedlings and saplings were species name and number of individuals. The following are the methods compared in this study.

\section{Line Strip Sampling Method}

This method is applied based on the Decree of the Director General of Forestry No: 60/Kpts/DJ/I/1978. The length of the transect line carried out in this study was 250 $\mathrm{m}$ and the number of transects was 3 transects per plot (Figure 2). The sample plot size for the tree growth stages was 2.25 ha $(250 \mathrm{~m} \times 10 \mathrm{~m} \times 3$ plots $\times 3$ replications $)$. The tree $\mathrm{DBH}$ was measured at a distance of $5 \mathrm{~m}$ on the right and left along the path. Inventory of the number of individuals and species name of sapling stage was carried out in a plot of $5 \mathrm{~m} \times 5 \mathrm{~m}$. Thus the sample plot size for the sapling stage was 0.045 ha $(5 \mathrm{~m} \times 5 \mathrm{~m} \times 6$ plots $\times 3$ replications). Inventory of the number of individuals and species name of seedlings stage was carried out every 100 $\mathrm{m}$ in a plot of $2 \mathrm{~m} \times 2 \mathrm{~m}$. Thus the sample plot size for seedlings stage was 0.0072 ha $(2 \mathrm{~m} \times 2 \mathrm{~m} \times 6$ plots $\times 3$ replications).

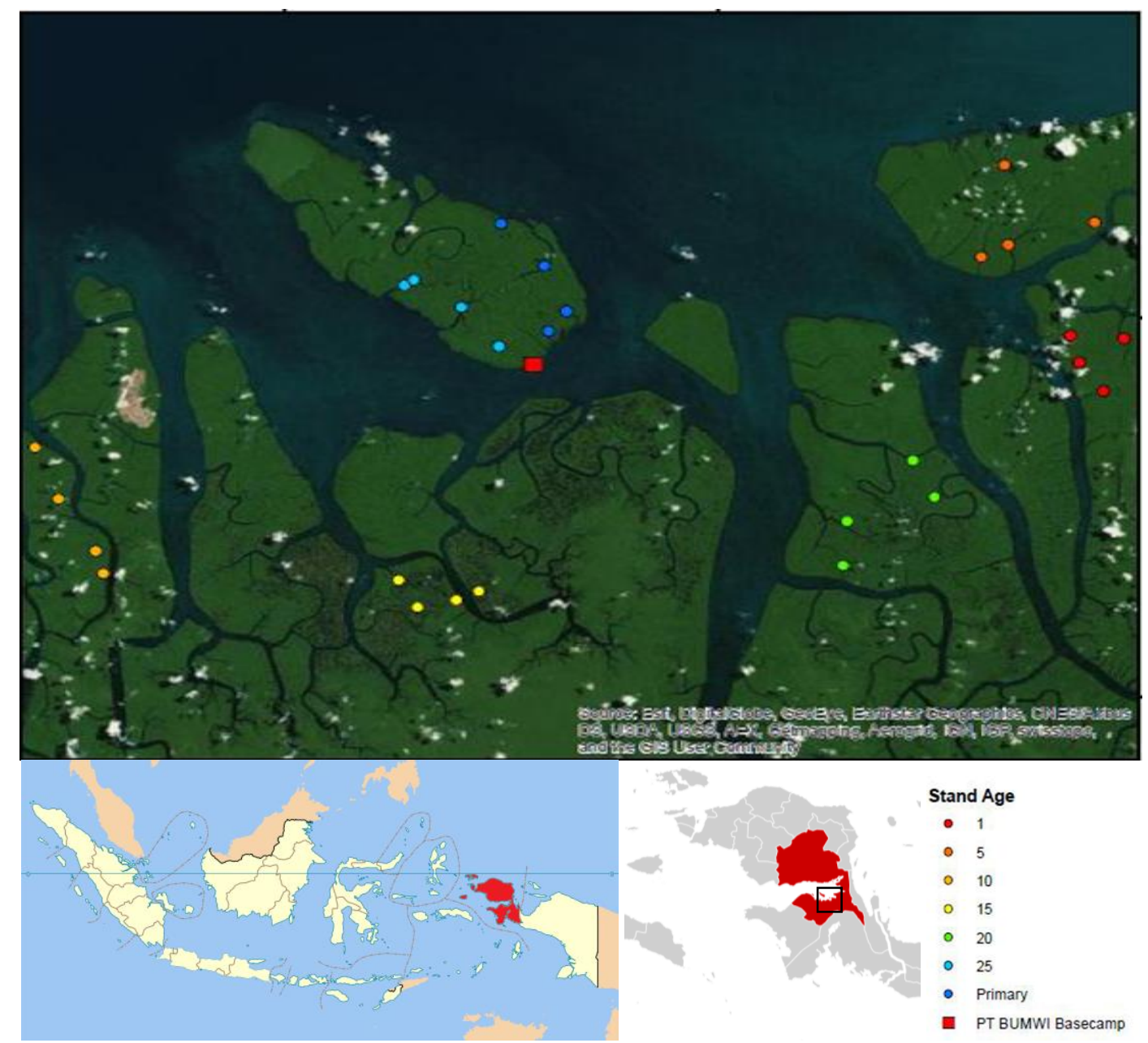

Figure 1. Map of the studied in a forest concession in Babo, Teluk Bintuni District, West Papua Province, Indonesia 


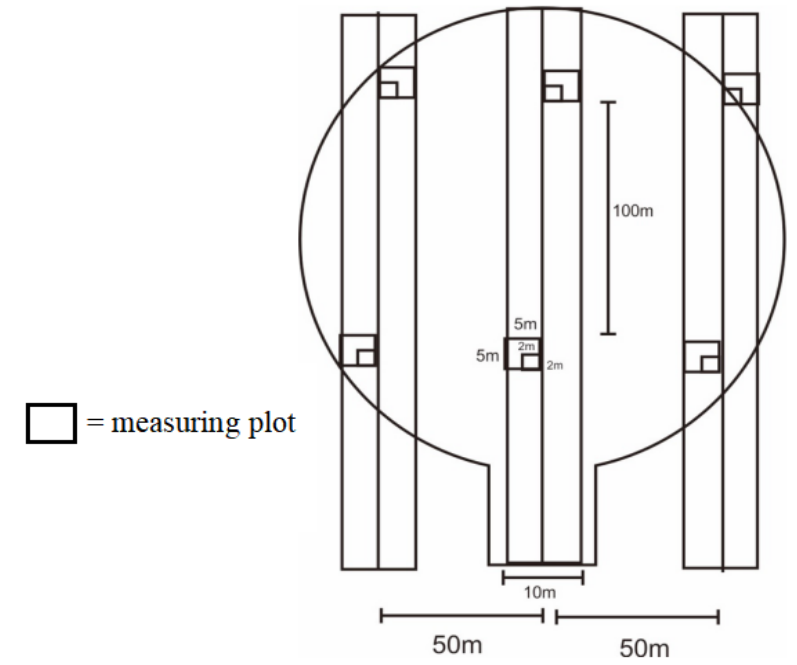

Figure 2. Line Strip Sampling Method Plot

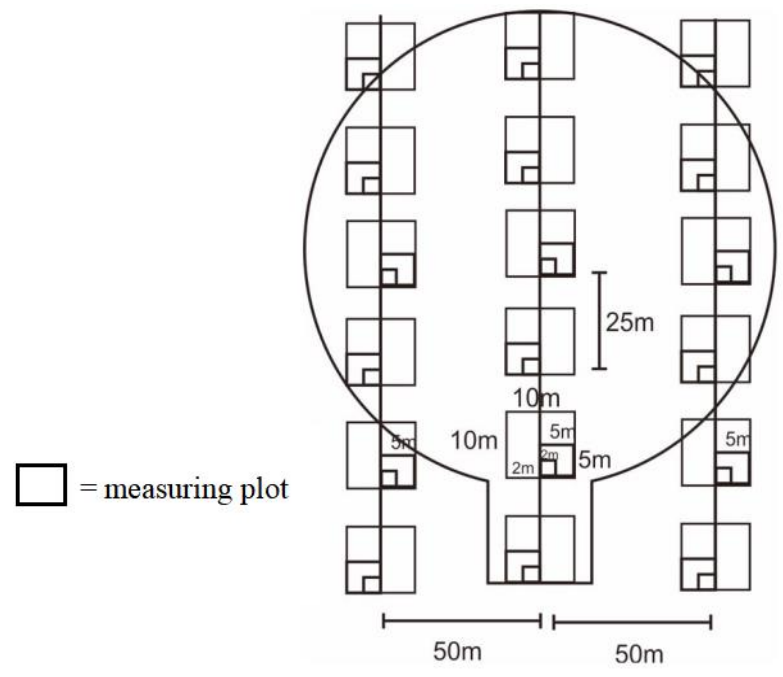

Figure 3. Line Systematic Sampling Method Plot

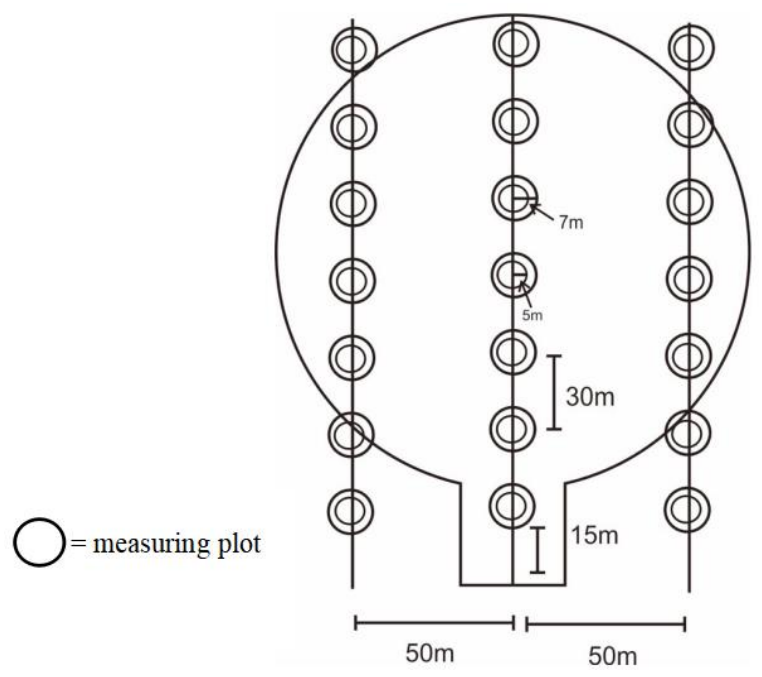

Figure 4. CIFOR Modified Method Plot

\section{Line Systematic Sampling Method}

This method used a $10 \mathrm{~m} \times 10 \mathrm{~m}$ quadrant plot in a transect line that is $25 \mathrm{~m}$ apart at the center of the plot (Figure 3). The tree DBH was measured in a plot of $10 \mathrm{~m} \mathrm{x}$ $10 \mathrm{~m}$, whereas the regenerations were measured in a plot of $5 \mathrm{~m} \times 5 \mathrm{~m}$ for saplings and $2 \mathrm{~m} \times 2 \mathrm{~m}$ for seedlings. The plot size for tree stage, sapling stage and seedlings stage were 0.54 ha $(10 \mathrm{~m} \times 10 \mathrm{~m} \times 18$ plots x 3 replications), 0.135 ha $(5 \mathrm{~m} \times 5 \mathrm{~m} \times 18$ plots $\times 3$ replications $)$, and 0.0216 ha $(2 \mathrm{~m} \times 2 \mathrm{~m} \times 18$ plot $\times 3$ replications $)$, respectively.

\section{CIFOR's Modified Method}

CIFOR's modified method is a modification of the method used in the research conducted by Silanpaa and Vantellingen (2015). This method uses a circular plot with a radius of $7 \mathrm{~m}$ to measure the tree $\mathrm{DBH}$. The plot size for tree size was 0.9702 ha $\left(154 \mathrm{~m}^{2} \times 21\right.$ plots $\times 3$ replications $)$. In terms of saplings and seedlings, the measurement was done by counting the number of individuals in a $5 \mathrm{~m}$ circular radius plot. The plot size for saplings and seedlings was 0.49455 ha $(78.5 \mathrm{~m} 2 \times 21$ plots $\times 3$ replications $)$. Figure 4 shows the plot used in the CIFOR modified method.

\section{Data analysis}

Species identification was carried out using species identification books and herbarium. Dried herbarium was made in the field for one leaf twig specimen and wet herbarium was made for flower and fruit specimens. Herbarium identification was then carried out at the Herbarium Bogoriense, Indonesian Institute of Sciences (LIPI) at Cibinong, West Java, Indonesia.

Vegetation analysis for the structure and composition of species used in this study is the Important Value Index (IVI). According to Soerianegara and Indrawan (2002), the Important Value Index is used to rank species according to their ecological importance. The IVI value of a tree is the sum of Relative Density (RD), Relative Frequency (FR), and Relative Dominance (RDo) while the IVI value of seedling and sapling is the sum of Relative Density (RD) and Relative Frequency (RF).

Density $=\frac{\text { Number of individual species in the sampling area }}{\text { SamplePlot Area }}$

Relative Density $=\frac{\text { Densityof a s pecies }}{\text { Desnsityof alls pecies }} \times 100 \%$

Frequency $=\frac{\sum \text { Plots inhabit by secies }}{\text { Number of alls arple plots }}$

Relative Frequency $=\frac{\text { Frequency of a species }}{\text { Frequency of allspecies }} \times 100 \%$

Dominance $=\frac{\text { Basalarea of a species }}{\text { Sampleplotarea }}$

Relative Dominance $=\frac{\text { Dominance of a species }}{\text { Dominance of alls pecies }} \times 100 \%$ 
Important Value Index (IVI) = Relative Density + Relative Frequency + Relative Dominance

Furthermore, the diameter data that have been obtained were converted into tree volume. The allometric volume equation used to convert the diameter to the tree volume was based on the equation developed for the logging concession (unpublished) and is formulated follows:

$$
V=1.21 \times 10^{-4} \times D^{2.54}
$$

Where,

$\mathrm{V}=$ Volume $\left(\mathrm{m}^{3}\right)$

$\mathrm{D}=$ Tree Diameter $(\mathrm{m})$

Another allometric equation used to compare the research result is the allometric equation used specifically for each species according to Cole et al. (1999). Each species has the following allometric volume equation:

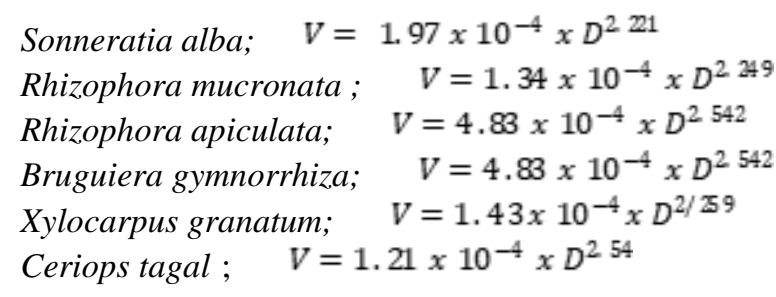

Where,

$\mathrm{V}=$ Volume $\left(\mathrm{m}^{3}\right)$

$\mathrm{D}=$ Tree Diameter $(\mathrm{m})$

Once converted to tree volume, it will be used to estimate the potential tree volume per hectare. The equation for estimating the volume of trees per hectare is as follows (Ministry of Environment and Forestry, 2016):

$$
\text { Volume perhectare }=\frac{\sum \text { Tree Volume }}{\text { ITSPArea }} \times 1 \text { ha }
$$

The experimental design used in this study was a completely randomized design consisting of three ITSP treatment methods (line strip sampling, line systematic sampling, CIFOR's modified method) and 3 sample plot replications. The tree volume per hectare of each method will be compared with the actual harvested volume. Tree volume data from the calculation will then be analyzed its variance using analysis of variance (ANOVA) to see the significant differences between the three ITSP methods used. This analysis is performed using the SPSS version 23 software (IBM Corp 2015). The variance analysis model used in this study is as follows (Mattjik and Sumertajaya 2006):

$$
\mathrm{Y}_{\mathrm{ij}}=\mu+\tau_{\mathrm{i}}+\epsilon_{\mathrm{ij}}
$$

Where,

$$
\begin{array}{ll}
\text { i } & : 1,2,3,4 \\
\text { j } & : 1,2,3
\end{array}
$$

Y : Observation value (tree volume from i-th treatments and $\mathrm{j}$-th replication)

$\mu$ : General average

$\tau_{\mathrm{I}}:$ The effect of i-th treatment

єij : The effect of experimental error from i-th treatment and $\mathrm{j}$-th replication

Variance testing with the $\mathrm{F}$ test was carried out to determine the effect of this treatment if (i) $p$-value $>\alpha$ (0.05), then the treatment did not have a significant effect on the observed parameters; (ii) p-value $<\alpha(0.05)$, then the treatment has a significant effect on the observed parameters, thus the test is continued with Duncan's Multiple Range Test.

\section{RESULTS AND DISCUSSION}

\section{Species composition}

The number of mangrove species found in the study site varied. The results of vegetation analysis at the seedling, saplings and trees stages can be seen in Tables 1, 2, and 3, respectively. At the seedling stage, 5 species (R. apiculata, B. gymnorrhiza, $R$. mucronata, B. parviflora, and $C$. tagal) were found in the Line Strip Sampling Method, 6 species (R. apiculata, B. gymnorrhiza, B. parviflora, $R$. mucronata, $C$. tagal, and $S$. alba) were found in the Line Systematic Sampling Method and 5 species ( $R$. apiculata, $B$. parviflora, B. gymnorrhiza, $C$. tagal, and $R$. mucronata) were found in the CIFOR's Modified Method (Table 1). The number of species found in the Line Strip Sampling Method, the Line Systematic Sampling Method and the CIFOR's Modified Method at the sapling stage were 5 species ( $R$. apiculata, $B$. gymnorrhiza, $C$. tagal, $R$. mucronata, and B. parviflora), 7 species (R. apiculata, $C$. tagal, B. gymnorrhiza, B. parviflora, R. mucronata, $X$. granatum, and $S$. alba) and 6 species (R. apiculata, $B$. parviflora, B. gymnorrhiza, R. mucronata, C. tagal, and $X$. granatum), respectively (Table 2 ). While, at tree stage, 6 species ( $R$. apiculata, B. parviflora, B. gymnorrhiza, $C$. tagal, $R$. mucronata, and $S$. alba) were found in the Line Strip Sampling Method, 6 species ( $R$. apiculata, $B$. gymnorrhiza, B. parviflora, $R$. mucronata, $S$. alba, and $C$. tagal) were found in the Line Systematic Sampling Method and 7 species (R. apiculata, B. parviflora, B. gymnorrhiza, $R$. mucronata, $C$. tagal, $S$. alba, and $X$. granatum) were found in the CIFOR's Modified Method (Table 3). The measurement results for the number of species indicate the balance between the number of seedling, saplings, and trees which range between 5 and 7 species from seedling to the tree stage. The results of the present study are in accordance with Silanpaa et al. (2017), who reported that mangrove stands in Bintuni Bay were composed of seven trees species, namely $R$. apiculata, $C$. tagal, $B$. gymnorrhiza, B. parviflora, $R$. mucronata, X. granatum, and $S$. alba. 
Table 1. Important Value Index (IVI) of seedlings

\begin{tabular}{lcccc}
\hline Species & $\begin{array}{c}\text { D } \\
\text { (ind/ha) }\end{array}$ & $\begin{array}{c}\text { RD } \\
(\%)\end{array}$ & $\begin{array}{c}\text { RF } \\
(\%)\end{array}$ & $\begin{array}{c}\text { IVI } \\
(\%)\end{array}$ \\
\hline Line Strip Sampling Method & & & \\
R. apiculata & 8055.56 & 51.79 & 35.71 & 87.50 \\
B. gymnorrhiza & 2638.89 & 16.96 & 17.86 & 34.82 \\
R. mucronata & 2083.33 & 13.39 & 17.86 & 31.25 \\
B. parviflora & 1805.56 & 11.61 & 17.86 & 29.46 \\
C. tagal & 972.22 & 6.25 & 10.71 & 16.96 \\
Total & 15555.56 & 100.00 & 100.00 & 200.00 \\
Line Systematic Sampling Method & & & \\
R. apiculata & 6620.37 & 52.96 & 46.57 & 99.54 \\
B. gymnorrhiza & 2129.63 & 17.04 & 8.22 & 25.26 \\
B. parviflora & 1759.26 & 14.07 & 17.81 & 31.88 \\
R. mucronata & 879.63 & 7.04 & 15.07 & 22.10 \\
C. tagal & 555.56 & 4.44 & 9.59 & 14.03 \\
S. alba & 555.56 & 4.44 & 2.74 & 7.18 \\
Total & 12500.00 & 100.00 & 100.00 & 200.00 \\
CIFOR Modified Method & & & & \\
R. apiculata & 313.42 & 44.54 & 48.31 & 92.85 \\
B. parviflora & 145.59 & 20.69 & 5.62 & 26.31 \\
B. gymnorrhiza & 141.54 & 20.11 & 16.85 & 36.97 \\
C. tagal & 58.64 & 8.33 & 22.47 & 30.81 \\
R. mucronata & 44.48 & 6.32 & 6.74 & 13.06 \\
Total & 703.67 & 100.00 & 100.00 & 200.00 \\
\hline
\end{tabular}

Note: D: Density, RD: Relative Density, RF: Relative Frequency, and IVI: Important Value Index
Table 3. Important Value Index of trees

\begin{tabular}{|c|c|c|c|c|c|}
\hline Species & $\begin{array}{c}\text { D } \\
\text { (ind/ha) }\end{array}$ & $\begin{array}{l}\text { RD } \\
(\%)\end{array}$ & $\begin{array}{l}\text { RF } \\
(\%)\end{array}$ & $\begin{array}{l}\text { RDo } \\
(\%)\end{array}$ & $\begin{array}{l}\text { IVI } \\
(\%)\end{array}$ \\
\hline \multicolumn{6}{|c|}{ Line Strip Sampling Method } \\
\hline R. apiculata & 308.89 & 57.82 & 20.93 & 55.74 & 134.49 \\
\hline B. parviflora & 104.44 & 19.55 & 11.63 & 13.20 & 44.38 \\
\hline B. gymnorrhiza & 64.44 & 12.06 & 20.93 & 16.80 & 49.79 \\
\hline C. tagal & 30.22 & 5.66 & 20.93 & 2.99 & 29.58 \\
\hline R. mucronata & 24.00 & 4.49 & 20.93 & 4.62 & 30.04 \\
\hline S. alba & 2.22 & 0.42 & 4.65 & 6.64 & 11.70 \\
\hline Total & 534.22 & 100.00 & 100.00 & 100.00 & 300.00 \\
\hline
\end{tabular}

\section{Line Systematic Sampling Method}

$\begin{array}{lccccc}\text { R. apiculata } & 427.78 & 54.61 & 33.33 & 46.04 & 133.99 \\ \text { B. gymnorrhiza } & 120.37 & 15.37 & 25.19 & 19.34 & 59.89 \\ \text { B. parviflora } & 151.85 & 19.39 & 21.48 & 10.45 & 51.31 \\ \text { R. mucronata } & 46.30 & 5.91 & 8.89 & 5.64 & 20.44 \\ \text { S. alba } & 3.70 & 0.47 & 1.48 & 16.56 & 18.52 \\ \text { C. tagal } & 33.33 & 4.26 & 9.63 & 1.97 & 15.85 \\ \text { Total } & 783.33 & 100.00 & 100.00 & 100.00 & 300.00\end{array}$

\section{CIFOR Modified Method}

$\begin{array}{lccccc}\text { R. apiculata } & 258.71 & 56.03 & 38.00 & 58.55 & 152.58 \\ \text { B. parviflora } & 83.49 & 18.08 & 9.33 & 14.32 & 41.73 \\ \text { B. gymnorrhiza } & 71.12 & 15.40 & 19.33 & 19.92 & 54.66 \\ \text { R. mucronata } & 25.77 & 5.58 & 22.67 & 6.97 & 35.22 \\ \text { C. tagal } & 19.58 & 4.24 & 8.67 & 0.14 & 13.04 \\ \text { S. alba } & 2.06 & 0.45 & 1.33 & 0.10 & 1.88 \\ \text { X. granatum } & 1.03 & 0.22 & 0.67 & 0.00 & 0.89 \\ \text { Total } & 461.76 & 100.00 & 100.00 & 100.00 & 300.00\end{array}$

Note: D: Density, RD: Relative Density, RF: Relative Frequency, RDo: Relative Dominance, and IVI: Important Value Index

\section{Dominant species at seedling stage}

The IVI value of seedlings using three different ITSP methods is presented in Table 1. Based on the three ITSP methods used in this study, there is one mangrove species that has the highest IVI across all methods namely $R$. apiculata (IVI $=87.50 \%$ in Line Strip Sampling, IVI $=$ 99.54\% in Line Systematic Sampling, and IVI $=92.85 \%$ in CIFOR Modified), indicating that $R$. apiculata is the dominant species and has an important role in the observed stand. The high IVI of $R$. apiculata seedlings creates a high probability that this species will also dominate the forest in the next rotation. Vegetation which has the smallest IVI $(7.18 \%)$ is $S$. alba, which was only found in the observed stand using the ITSP method of Line Systematic Sampling.

\section{Dominant species at sapling stage}

The IVI of saplings using three different ITSP methods is presented in Table 2. Based on this table, R. apiculata has the highest IVI value across the three ITSP methods $(\mathrm{IVI}=61.42 \%$ in Line Strip Sampling, IVI $=83.23 \%$ in Line Systematic Sampling, and IVI $=63.45 \%$ in CIFOR Modified). This result is in accordance with the research reported by Silanpaa et al. (2017). The species of $S$. alba was only found using the Line Strip Sampling method with an IVI value of $2.39 \%$. Saplings of $X$. granatum were found on the Line Systematic Sampling and CIFOR's modified method plots with IVI values of $2.39 \%$ and $1.82 \%$ respectively. The species of $X$. granatum are indeed the rarest species observed and is only found in secondary 
stands of 20-25 years old and pristine forests (Silanpaa et al. 2017).

\section{Dominant species at tree stage}

Tree vegetation that has the highest IVI value across all three methods is $R$. apiculata (IVI $=134.49 \%$ in Line Strip Sampling, IVI $=133.99 \%$ in Line Systematic Sampling, and IVI $=152.58 \%$ in CIFOR Modified). This species has the highest IVI value at each growth stage which indicates that this species has an important role in the Bintuni Bay mangrove ecosystem. This condition is consistent with the results of a survey conducted by Silanpaa and Vantellingen (2015) and Silanpaa et al. (2017). Wahyudi et al. (2013) also found that the species of $R$. apiculata and $R$. mucronata were the most common species found in the mangroves of Bintuni Bay with a density of $69 \%$ of the entire population followed by $B$. spp. $20 \%$ and $C$. tagal $10 \%$. In line with these results, Onrizal and Mansor (2016) also stated that in 2005 (a year after the Aceh tsunami) $R$. mucronata and $R$. apiculata dominated mangrove ecosystems on the north coast of Sumatra. S. spp. was only found in plots using the Line Systematic Sampling method even though the density and IVI were low. This shows that different inventory methods affect the number of distribution of species found.

Rhizophora apiculata (Kusmana and Watanabe 1991) and R. mucronata (Nybacken 1992) are shade-intolerant species, thus allowing this species to grow dominantly on harvested sites. In addition, the ability of fast root growth makes it easier for the species of Rhizophora to grow and dominate the mangrove ecosystem in Bintuni Bay compared to species with low root growth ability such as C. tagal (De Ryck et al. 2012). The research results of Rahmat et al. (2015) shows that the transition from the dry season to the rainy season is one indication of the root's adjustment in the balance system for adaptation. It is known that $R$. apiculata is a family of Rhizophoraceae which has many roots and extends towards the soil surface. This is a way to adapt in cases of low oxygen levels. Apart from ecological aspects, $R$. apiculata also has good potential to be used as wood chips. Mangrove wood itself can be used for carpentry, boat building, chips, charcoal construction, and fuel (Da Silva et al. 1993; Duke et al. 2002). Moreover, the bark of trees is rich in tannin, which is used in some industrial processes (Da Silva et al. 1993; Duke et al. 2002).

\section{Stand structure}

The structure of the stand can be viewed horizontally and vertically. Horizontal stand structure can be seen based on the relationship of individual density/ha with the growth rate or class diameter of the tree so that it will describe the condition of a forest stand. The structure of the stands at the study site based on growth rates (seedlings, saplings, and trees) and based on diameter classes can be seen in Figure 5 and Figure 6, respectively.

Figure 5 shows that the number of individuals per hectare decreases as the growth stage moves toward maturity. Most individuals found were at the seedling stage, while the least was found at the growth stage of the tree. This graph forms an inverse $\mathrm{J}$ curve showing that the growth of natural forest stands in that location are not the same age, in this case, tree stands and their regeneration are in normal conditions (Meyer and Stevensonand 1961; Sorianegara and Indrawan 2002).

Figure 6 shows that the number of individuals decreases as the diameter class increases, forming an inverse $\mathrm{J}$ curve. This condition is normal due to the regeneration of a stand. Reduction in the number of individuals occurs due to competition and death, while the seedlings and saplings continue to grow into larger individuals. Regeneration of mangrove stands itself is influenced by various factors, both from external factors (environment) and internal factors (genetic factors). According to Cunha et al. (2006), leaf shedding of mangrove trees will affect the sustainability of the regeneration process.

The stand structure and composition of species need to be maintained to prevent changes in the ecosystem which can have negative impacts such as the loss of a particular plant species. The dominance of one plant species should also be considered because of its ability to suppress the growth rate of other species, and can even cause a stand to become monoculture. This is certainly not ideal for the ecosystem due to the fact that the higher the uniformity, the higher the chances of vulnerability to damage (Bosire et al. 2006).

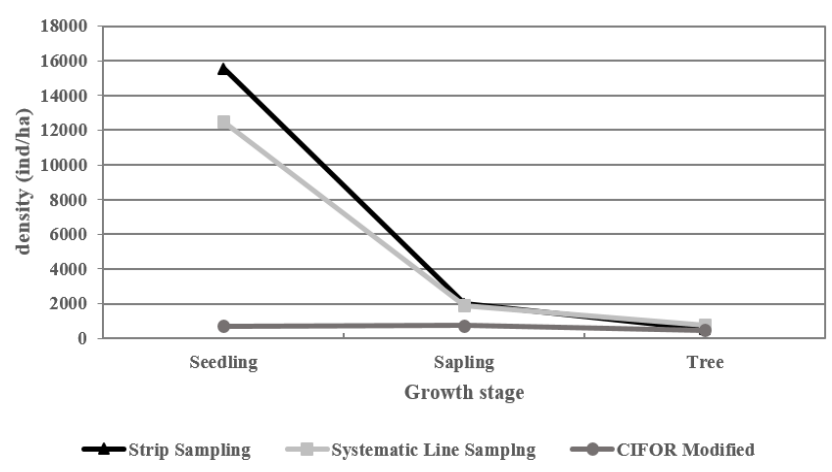

Figure 5. Number of individuals at each growth stage based on each ITSP method

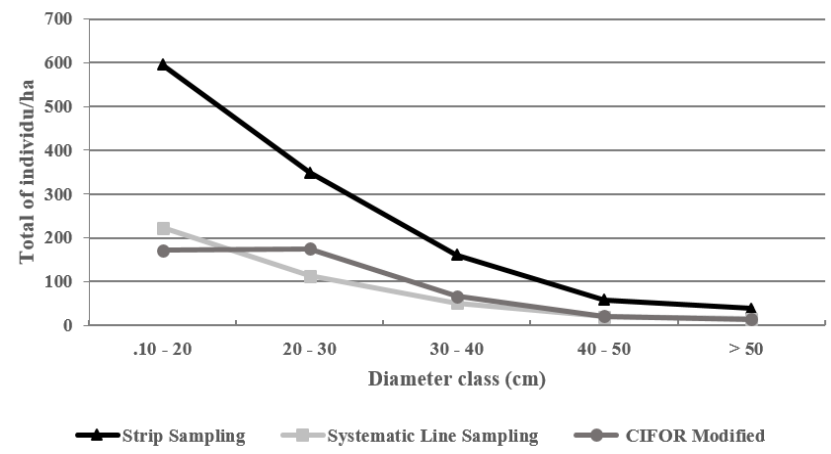

Figure 6. Number of individual according to diameter distribution based on each ITSP method 
The patterns in Figures 5 and 6 are in line with the general shape of the diameter class distribution (the inverse exponential $\mathbf{J}$ shape), which indicates that the larger the diameter class, the smaller the density. The number of trees decreases along with the increase in size so that only a few trees with large diameter are left (Hilwan 2012; Oladoye et al. 2014). Natural forest stands have dynamic growth because this growth is not only caused by the increase in the dimensions of the tree that creates the stand but also due to the emergence of new individuals so that there is a change in the trees that create the stands over time (Suhendang et. al. 1995; Prasetyo 2006; Hilwan 2012).

\section{Comparison of ITSP methods in term of estimated volume and actual harvested volume}

The comparison between the actual harvested volume and the volume estimated from the three ITSP methods can be seen in Table 4 . The estimated volume was calculated using a specific allometric volume equation developed for the logging concession in the studied area (see Methods).

Based on Table 4 it can be seen that the average volume of tree with diameter $\geq 10 \mathrm{~cm}$ estimated using the three ITSP methods with allometric equations specifically developed for the logging concession produces values that are much higher than the actual harvested volume. The difference between the average volume of the Line Strip Sampling method with the average volume of the actual harvested is $162.83 \mathrm{~m}^{3} / \mathrm{ha}$. This difference is the smallest among the other methods used, although it is still considered as a large overestimate. However, analysis of variance to statistical test difference among volume estimated using the three ITSP methods and actual harvested shows that the $p$-value is 0.3446 , indicating that four methods are not significantly different at the $95 \%$ confidence level (Table 5). Thus the three ITSP methods are incompatible when employing the allometric equation specifically developed for the logging concession due to the lack of accuracy in estimating the harvested volume, as seen it is almost double the actual harvested volume (Figure 7).

The allometric equation uses tree diameter to estimate the harvested volume and has been used to estimate the volume of all species of mangrove trees in the logging concession area. Allometric equations created by the logging concession (unpublished) have a tendency that these equations are formulated using a large number of tree samples and a large diameter range, this will increase the difference in value when repeated measurements are done due to dynamic tree growth. On the other hand, each allometric equation is developed based on stand conditions and certain species variations that differ from one another (Sutaryo 2009). Thus the use of an equation developed in a particular location is not necessarily suitable when applied to other areas.

The allometric equation specifically developed for the logging concession is applied to all species of trees inventoried. However, if there are differences in increment levels among species, their growth will be considered the same. This is likely the cause of the gap between the actual harvested yield and the estimated stand volume (i.e., overestimation) which has been often complained by the management. In addition to the allometric equation used by the logging concession, we then used several allometric equations from Cole et al. (1999) to estimate the ITSP volumes. The average value of estimated stand volume using allometric equations from Cole et al. (1999) in this study is presented in Table 6 .

Based on Table 6, the average tree volume estimated using the three ITSP methods ranges from 153.99 to 250.00 $\mathrm{m}^{3} /$ ha. These results are similar to the study of Kairo et al. (2002) in Lamu, Kenya, which reported the standing volume range between 6.85 to $710.0 \mathrm{~m}^{3} /$ ha for stem with a diameter above $5.0 \mathrm{~cm}$ and the average volume of the entire study area was $145.88 \mathrm{~m}^{3} / \mathrm{ha}$. The study of Phan et al. (2019) reported tree volume for R. apiculata plantations in Vietnam with a range of ages from 14 to 24 years having tree volumes of $142.1 \pm 38.5 \mathrm{~m}^{3} /$ ha to $175.8 \pm 55.7 \mathrm{~m}^{3} / \mathrm{ha}$. The results of Heriyanto and Subiandono (2012) research in Alas Purwo National Park, East Java, Indonesia reported that the volume of the $R$. mucronata tree has a volume of $236.11 \mathrm{~m}^{3} /$ ha (number of trees $=1033$ individuals $/ \mathrm{ha}$ ), $B$. cylindrica has a volume of $127.1 \mathrm{~m}^{3} /$ ha (number of trees $1377 / \mathrm{ha}$ ) and $X$. moluccensis $9.35 \mathrm{~m}^{3} /$ ha (number of trees 167 individuals/ha)

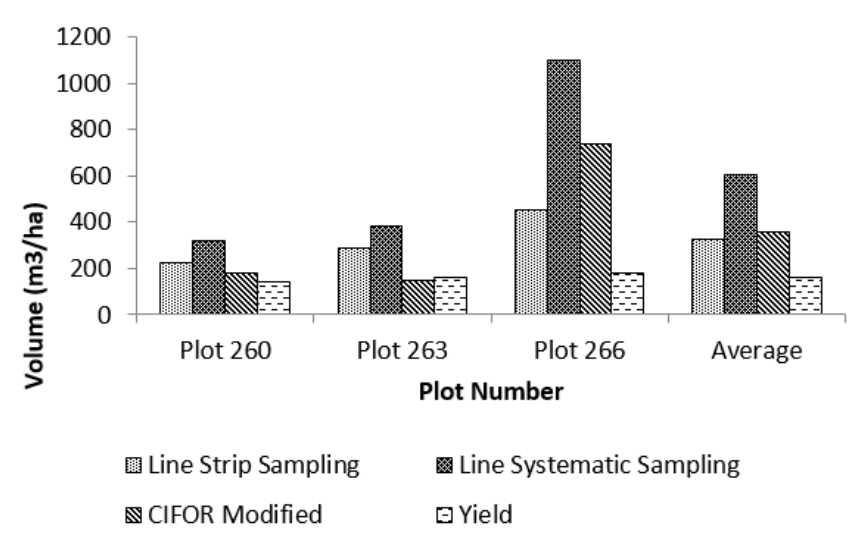

Figure 7. The comparison of tree volume per hectare estimated using the three ITSP methods (with allometric equation specifically developed for the logging concession) and actual harvested

Table 4. The estimated volume of trees (diameter $\geq 10 \mathrm{~cm}$ ) based on the allometric volume equation.

\begin{tabular}{lcccc}
\hline \multirow{2}{*}{ Method } & \multicolumn{2}{c}{$\begin{array}{c}\text { Volume of tree ( diameter } \geq \mathbf{1 0} \\
\mathbf{c m}) \text { of each logging } \mathbf{p l o t s}\left(\mathbf{m}^{\mathbf{3}} / \mathbf{h a}\right)\end{array}$} & $\begin{array}{c}\text { Average } \\
\left(\mathbf{m}^{\mathbf{3}} / \mathbf{h a}\right)\end{array}$ \\
\cline { 2 - 5 } & Plot 260 & Plot 263 & Plot 266 & \\
\hline Line Strip Sampling & 226.65 & 285.71 & 455.61 & 322.66 \\
Line Systematic Sampling & 322.56 & 383.91 & 1098.98 & 601.82 \\
CIFOR modified & 179.45 & 149.18 & 740.47 & 356.46 \\
Actual Harvested & 140.35 & 159.74 & 179.40 & 159.83 \\
\hline
\end{tabular}

Note: p-value 0.6 , not significantly different in the estimation of tree volume 
Table 5. Analysis of variance to test statistical difference among volume estimated using the tree ITSP methods (with allometric equation specifically developed for the logging concession) and actual harvested

\begin{tabular}{lccccc}
\hline \multicolumn{1}{c}{ Source } & DF & $\begin{array}{c}\text { Sum of } \\
\text { square }\end{array}$ & $\begin{array}{c}\text { Mean } \\
\text { square }\end{array}$ & F value & Pr>F \\
\hline Model & 3 & 299852.8278 & 99950.9426 & 1.28 & 0.3446 \\
Error & 8 & 623421.5622 & 77927.6953 & & \\
Corrected total & 11 & 923274.3900 & & & \\
\hline
\end{tabular}

Note: p-value $>\alpha(0.05)$, then the treatment did not have a significant effect on the observed parameters

Table 6. The estimated volume of trees (diameter $\geq 10 \mathrm{~cm}$ ) based on the allometric volume equation of Cole et al. (1999)

\begin{tabular}{|c|c|c|c|c|}
\hline \multirow{2}{*}{ Method } & \multicolumn{3}{|c|}{$\begin{array}{c}\text { Volume of tree ( diameter } \geq 10 \\
\mathrm{~cm}) \text { of each logging plots }\left(\mathrm{m}^{3} / \mathrm{ha}\right)\end{array}$} & \multirow{2}{*}{$\begin{array}{r}\text { Average } \\
-\left(\mathbf{m}^{3} / \mathbf{h a}\right) \\
\end{array}$} \\
\hline & Plot 260 & Plot 263 & Plot 266 & \\
\hline Line Strip Sampling & 107.27 & 147.76 & 197.91 & 150.98 \\
\hline Line Systematic Sampling & 148.51 & 192.55 & 408.92 & 250.00 \\
\hline CIFOR modified & 85.97 & 77.53 & 298.47 & 153.99 \\
\hline Actual Harvested & 140.35 & 159.74 & 179.40 & 159.83 \\
\hline
\end{tabular}

Table 7. Analysis of variance of tree volume based on tree volume allometric of Cole et al (1999)

\begin{tabular}{lccccc}
\hline \multicolumn{1}{c}{ Source } & DF & $\begin{array}{c}\text { Sum of } \\
\text { square }\end{array}$ & $\begin{array}{c}\text { Mean } \\
\text { square }\end{array}$ & F value & Pr>F \\
\hline Model & 3 & 20453.39630 & 6817.79877 & 0.73 & 0.5643 \\
Error & 8 & 75089.43207 & 9386.17901 & & \\
Corrected total & 11 & 95542.82837 & & & \\
\hline
\end{tabular}

Note: p-value $>\alpha(0.05)$, not significantly different at the $95 \%$ confidence level in the estimation of tree volume
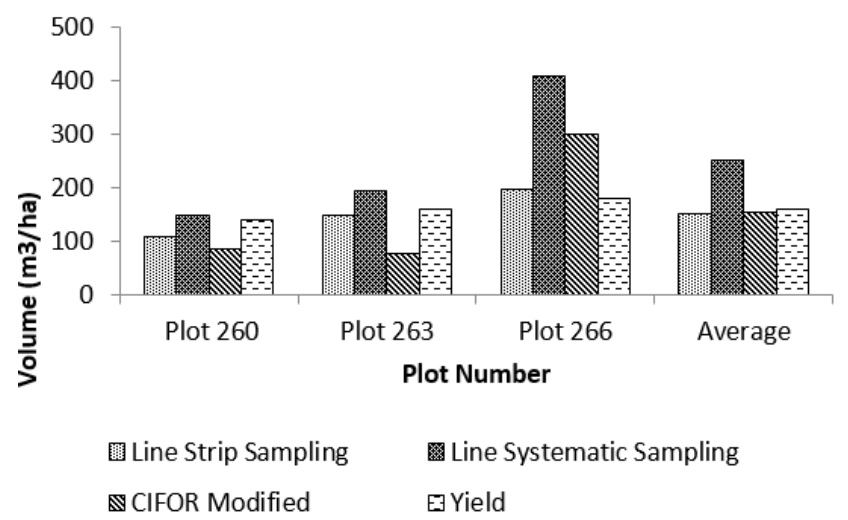

Figure 8. The comparison of tree volume per hectare estimated using the three ITSP methods with allometric equation using Cole et al. (1999) and actual harvested
The advantage of the equation developed by Cole et al. (1999) is that it is specific to each species which will increase the accuracy of the estimated data, resulting in a lower difference of measurement between the three ITSP methods compared to the harvested results. CIFOR modified ITSP method has the smallest difference with $5.82 \mathrm{~m}^{3} / \mathrm{ha}$, followed by the Line Strip Sampling method with a difference of $8.86 \mathrm{~m}^{3} / \mathrm{ha}$, while the Line Systematic Sampling has the largest difference.

The analysis of variance to test statistical difference among volume estimated using the three ITSP methods with allometric equations of Cole et al. (1999) and actual harvested showed is presented in Table 7 . The analysis of variance shows that the $p$-value is 0.5643 , indicating that four methods are not significantly different at the $95 \%$ confidence level (Table 7). This indicates that the three ITSP methods combined with the Cole et al. (1999) allometric equation can be used to estimate the harvested volume of trees (diameter $\geq 10 \mathrm{~cm}$ ) more accurately.

When using the allometric equation of Cole et al. (1999) to estimate volume of trees (diameter $\geq 10 \mathrm{~cm}$ ), the Line Strip Sampling method and the CIFOR modified method have an average tree volume per hectare closer to the actual harvested (Figure 8). Thus, in general, the allometric equation developed by Cole et al. (1999) is more suitable when combined either with the CIFOR modified method or the Line Strip Sampling method to estimate volume of trees (diameter $\geq 10 \mathrm{~cm}$ ) in units of area as these methods have the closest value to the actual harvested volume.

In conclusion, the three ITSP methods used in this study have their own advantages and disadvantages. The plot size in CIFOR's Modified Method is smaller than other methods. This will certainly simplify and shorten the time for data collection. As stated by Siahaan et al. (2012) that square sample plots are more time-consuming. This is due to the addition of time for creating the boundaries in the sample unit and the use of a compass to reduce the perpendicular angle bias which is quite difficult. However, CIFOR's Modified Method also has disadvantage when applied in the field due to difficulties in making a circular plot, which causes unclear plot boundaries. The Line Strip Sampling ITSP method is more applicable to be used than other methods because it is easy to create a straight line in the field. However, the Line Strip Sampling method also has disadvantage, which is the lack of representation of seedlings and saplings. Therefore, additional plots for seedlings and saplings data collection are needed, not only for every $100 \mathrm{~m}$.

\section{ACKNOWLEDGEMENTS}

The authors thank the Director of PT BUMWI for providing financial support to this research, especially for logistics, transportation, and also field assistance for data collection. 


\section{REFERENCES}

Alongi DM. 2012. Carbon sequestration in mangrove forest. Carbon Manag 3 (3): 313-322.

Bosire JO, Dahdouh-Guebass F, Kairo JG, Wartel S, Kazungu J, Koedam N. 2006. Success rates of recruited tree species and their contribution to the structural development of reforested mangrove stands. Mar Ecol Prog Ser 325: 85-91.

Cole TG, Ewel KC, Devoe NN. 1999. Structure of mangrove trees and forestry in Micronesia. Forest Ecol Manag 117: 95-109.

Cunha SR, Togenella-de-Rosa MMP, Costa CSB. 2006. Structure and litter production of mangrove forests under different tidal influences in Babitonga Bay, Santa Catarina, Southern Brazil. J Coast Res SI II (39): 1169-1174.

Da Silva JAA, De Melo MRCS, Borders BE. 1993. A volume equation for mangrove trees in northeast Brazil. For Ecol Manag 58: 129-136.

de Ramos RMQ, Abundo MLS, Taboada EB. 2017. Life cycle assessment of secondary mangrove forest in Bintuni Bay, West Papua, Indonesia. Curr World Environ 12 (3): 616-627.

De Ryck DJR, Robert EMR, Schmitz N, der Stcoken TV, Nitto DD, Dahdouh-Guebas F, Koedam N. 2012. Size does matter, but not only size: Two alternative dispersal strategies for viviparous mangrove propagules. Aquat Bot 103: 66-73.

Duke NC, Lo E, Sun M. 2002. Global distribution and genetic discontinuities of mangroves-emerging patterns in the evolution of Rhizophora. Trees 16: 65-79.

FAO. 2001. Global Forest Resource Assessment 2000. FAO, Rome.

Forest Watch Indonesia (FWI/GFW). 2001. Keadaaan Hutan Indonesia. Forest Watch Indonesia dan Washington DC: Global Forest Watch, Bogor, Indonesia. [Indonesian]

Friess DA, Thompson BS, Brown B, Aldier Amir A, Cameron C, Koldewey HJ, Sasmito SD, Sidik F. 2016. Policy challenges and approaches for the conservation mangrove forest in Southeast Asia Conserv Biol 30 (5): 933-949.

Gasparini P, Cosmo LD, Rizzo M, Giuliani D. 2017. A stand-level model derived from national forest inventory data to predict periodic annual volume increment of forest in Italy. J For Res 22 (4): 209-217.

Giri C, Ochieng E, Tieszen LL, Zhu Z, Singh A, Loveland T, Masek J, Duke N. 2011. Status and distribution of mangrove forest of the world using earth observation satellite data. Glob Ecol Biogeogr 20 (1) 154-159.

Heriyanto NM, Subiandono E. 2012. Composition and structure, biomass, and potential of carbon content in mangrove forest at National Park Alas Purwo. Jurnal Penelitian hutan dan Konservasi Alam 9 (1): 23 32. [Indonesian]

Hilwan I. 2012. Species composition and stand structure in logged over area in forest concession of PT Salaki Summa Sejahtera, Province of West Sumatra. Jurnal Silvikultur Tropika 3 (3): 155-16. [Indonesian]

IBM Corp. 2015. IBM SPSS Statistics for Windows, Version 23.0. IBM Corp, Armonk, NY.

Istomo, Kusmana C, Naibaho BD. 2017. Biomass potential on several mangrove planting models in Java Island, Indonesia. AACL Boflux 10 (4): 754-967.

Kairo JG, B Kivyatu, N. Koedam. 2002. Application of remote sensing and GIS in the management of Mangrove forest within and adjacen to Kiunga Marine Protected Area, Lamu, Kenya. Environ Dev Sustain 4: 153-166.

Kusmana C, Hidayat T, Istomo, Rusdiana O. 2018. Growth performance of $B$. gymnorrhiza derived from cut-propagule seedling. Biodiversitas 19 (1): 208-214.

Kusmana C, Watanabe H. 1991. Production structure of main commercial tree species in a mangrove forest in East Sumatera, Indonesia. Biotropia 5: 1-9.

Mattjik AA, Sumertajaya IM. 2006. Perancangan Percobaan dengan Aplikasi SAS dan Minitab. IPB Press, Bogor. [Indonesian]

Meyer HA, Recknagel AB, Stevenson DD, Bartoo RA. 1961. Forest Management 2nd ed. The Ronald Press Company, New York.

Ministry of Agriculture. 1978. Regulations of The Director General of Forestry No. 60/Kpts/DJ///1978 Concerning Guidelines for Silviculture Systems in Mangrove Forests. Director General of Forestry, Directorate General of Forestry, Indonesia.

Ministry of Environment and Forestry. 2016. Regulations of The Director General of Sustainable Production Forest Management
No.P.8/PHPL/SET/3/2016 Concerning Guidelines for Silviculture Systems in Mangrove Forests. Director General of Sustainable Production Forest Management, Directorate General of Sustainable Production Forest Management, Indonesia.

Mirmanto E. 2010. Vegetation analyses of Sebangau peat swamp forest, Central Kalimantan. Biodiversitas 11 (2): 82-88.

Mitra A, Sengupta K, Banerjee K. 2011. Standing biomass and carbon storage of above-ground structures in dominant mangrove trees in the Sundarbans. For Ecol Manag 261 (7): 1325-1335.

Nontji A. 2002. Laut Nusantara. Jakarta (ID), Djambatan

Oladoye AO, Aduradola AM, Adedire MO, Agboola DA. 2014. Composition and stand structure of regenerating tropical rainforest ecosystem in South-western Nigeria. Intl J Biodivers Conserv. 6 (11): 765-776

Onrizal, Mansor M. 2016. Status of coastal forest of the Northern Sumatra in 2005 (after 2004's tsunami catastrophe). Biodiversitas 17 (1): 4454

Phan SM, HTT Nguyen, TK Nguyen, C Lovelock. 2019. Modelling above ground biomass accumulation of mangrove plantations in Vietnam. For Ecol Manag 432: 376-386.

Prasetyo D. 2006. Kajian Komposisi dan Struktur Tegakan serta Pertumbuhan Jenis-jenis Komersial, Khususnya Jenis Ramin (Gonystylus bancanus (Miq.) Kurz.) di Hutan Rawa Gambut IUPHHK PT. Diamond Raya Timber, Propinsi Riau. [Hon. Thesis]. Fakultas Kehutanan, Institut Pertanian Bogor, Bogor. [Indonesian]

Pribadi R.1998. The ecology of mangrove vegetation in Bintuni Bay, Irian Jaya, Indonesia. [Dissertation]. Universitas Stirling, Skotlandia

Rahmat D, Fauziyah, Sarno. 2015. Seedling growth of $R$. apiculata at mangrove restoration area Sembilang National Park South Sumatera. Jurnal Maspari 7 (2): 11-18. [Indonesian]

Saputro GB, Hartini S, Sukardjo S, Sutanto A, Kertopermono AP. 2009. Peta Mangroves Indonesia. Bakosurtanal, Bogor, Indonesia.

Setyawan AD, Winarno K. 2006. The direct exploitation in the mangrove ecosystem in Central Java and the land use in its surroundings; degradation and its restoration effort. Biodiversitas 7 (3): 282-291. [Indonesian]

Siahaan OP, Latifah S, Afifuddin Y. 2012. The comparison of circular plots and tree sampling on potential guessed stands at pine public plant forest, case study of Pondok Buluh Village, Subdistrict of Dolok Panribuan, Simalungun Regency. Peronema Forestry Science Journal 1 (1): 1-6. [Indonesian]

Silanpaa M, Vantellingen J, Friess D. 2017. Vegetation regeneration in a sustainably harvested mangrove forest in West Papua, Indonesia. For Ecol Manag 390: 137-146.

Silanpaa M, Vantellingen J. 2015. Forest Survey Report: Assessing Secondary Mangrove Forest Regeneration in PT BUMWI concessions, Bintuni Bay, West Papua. Green Forest Product \& Tech. Pte. Ltd., Research Department, Indonesia

Soerianegara I, Indrawan A. 2002. Ekologi Hutan Indonesia. Laboratorium Ekologi Hutan, Fakultas Kehutanan IPB, Bogor. [Indonesian]

Suhendang E, SooerianegaraI, Rusolono T, Prihanto B, Purnomo H, dan Muhdin. 1995. Petunjuk Operasional Metode Pengaturan Hasil Berdasarkan Jumlah Pohon pada Hutan Alam Campuran Tidak Seumur. Fakultas Kehutanan, Institut Pertanian Bogor, Bogor. [Indonesian]

Sutaryo D. 2009. Perhitungan Biomassa: Sebuah Pengantar untuk Studi Karbon dan Perdagangan Karbon. Wetlands International Indonesia Programme, Bogor, Indonesia. [Indonesian]

Valiela I, Bowen JL, York JK. 2001. Mangrove forest: one of the world's threatened major tropical environments. Bioscience 51 (10): 807-815.

Van Oudenhoven APE, Siahainenia AJ, Sualia I, Tonneijk FH, van der Ploeg S, de Groot RS, Alkemade R, Leemans R. 2015. Effects on different management regimes on mangrove ecosystem services in Java, Indonesia. Ocean Coast Manage116: 353-367.

Wahyudi, Machmud, Sudjarmaji. 2013. Seed trees method system of silviculture for harvesting and managing mangrove forest in Indonesia: study case learned from Bintuni Bay, West Papua after being in practices from 24 years. J Sustain 100: 1-7.

Wanggai F. 2009. Manajemen Hutan. Grasindo, Jakarta, Indonesia. [Indonesian] 